\title{
BATCH ETHANOL FERMENTATION: THE CORRELATION BETWEEN THE FERMENTATION EFFICIENCY AND THE BIOMASS INITIAL CONCENTRATION DEPENDS ON WHAT IS CONSIDERED AS PRODUCED ETHANOL
}

\author{
Walter Borzani \\ Instituto Mauá de Tecnologia, Escola de Engenharia Mauá, São Caetano do Sul, SP, Brazil \\ Submitted: June 09, 2005; Returned to authors for corrections: September 22, 2005; Approved: February 03, 2006

\section{SHORT COMMUNICATION}

\begin{abstract}
Although numerous studies have examined many of the factors that affect the efficiency of batch ethanol fermentation, little attention has been paid to the influence of the biomass concentration on this efficiency. This paper shows that the influence of the biomass initial concentration on the fermentation efficiency depends on what is considered "produced ethanol". If only the ethanol present in the medium aqueous phase at fermentation completion is considered, the fermentation efficiency linearly decreases when the biomass initial concentration increases. If, however, the intracellular ethanol is also considered as produced ethanol, the fermentation efficiency is not affected by the biomass concentration.
\end{abstract}

Key words: ethanol fermentation efficiency, intracellular ethanol, biomass concentration

Although numerous studies have examined many of the factors that affect the efficiency of batch ethanol fermentation, little attention has been paid to the influence of the biomass concentration on the above efficiency.

Falcone et al. (4) reported that the efficiency of batch ethanol fermentation of sugar-cane blackstrap molasses media decreased when the biomass initial concentration increased. No correlation between the fermentation efficiency and the biomass concentration, nor interpretation of the observed facts, however, were presented.

The main purpose of this paper is to show that the influence of the biomass initial concentration on the fermentation efficiency depends on the adopted definition of "produced ethanol", that is, depends on to considerer also the intracellular ethanol as "produced" ethanol.

A process carried out with no cell recycle, due to its importance in laboratory-scale experiments and in some industrial fermentations, will initially be considered.

Compressed yeast (Saccharomyces cerevisiae) was used as inoculum in all the experiments. The fermentation media, prepared in volumetric flasks, were aqueous (distilled water) solutions containing glucose $(100.0,150.0$ and $200.0 \mathrm{~g} / \mathrm{L})$, $\mathrm{KH}_{2} \mathrm{PO}_{4}(6.0 \mathrm{~g} / \mathrm{L})$, urea $(2.5 \mathrm{~g} / \mathrm{L})$, yeast extract $(2.5 \mathrm{~g} / \mathrm{L})$ and $\mathrm{MgSO}_{4} .7 \mathrm{H}_{2} \mathrm{O}(1.3 \mathrm{~g} / \mathrm{L})$. The experiments were carried out in 500$\mathrm{mL}$ unstirred Erlenmeyer flasks connected to water-cooled reflux condensers (cooling water temperature, $5-10^{\circ} \mathrm{C}$ ) in order to minimize evaporation/stripping losses. To each Erlenmeyer flask, containing $300 \mathrm{~mL}$ of fermentation medium, a calculated mass of compressed yeast was added in order to obtain the desired biomass initial concentration $(\sim 7 \mathrm{~g} / \mathrm{L}, \sim 20 \mathrm{~g} / \mathrm{L}$ and $\sim 45 \mathrm{~g} / \mathrm{L}$, dry matter). The flasks were then incubated at $32.0 \pm 0.5^{\circ} \mathrm{C}$ until fermentation completion. The ethanol and glycerol concentrations were measured in the centrifuged $(1,800 \mathrm{x} \mathrm{g} ; 10$ min) medium by the dichromate method (6) and by the enzymatic method proposed by Gattas et al. (5), respectively. The biomass concentrations were measured as follows: $5.0 \mathrm{~mL}$ of medium was filtered (Millipore membrane; pores diameter, $1.2 \mu \mathrm{m}$ ); the collected cells were washed ( $50 \mathrm{~mL}$ of distilled watter) and then dried $\left(105^{\circ} \mathrm{C} ; 4 \mathrm{~h}\right)$ and weighed.

Considering only the ethanol present in the medium aqueous phase, the fermentation efficiency $(\eta)$ is defined by Equation 1, where $M_{S}$ is the glucose initial mass, $M_{E}$ is the ethanol final

*Corresponding Author. Mailing address: Escola de Engenharia Mauá, Praça Mauá 1. 09580-900, São Caetano do Sul, SP, Brasil. Tel.: (+5511) 42393119, Fax: (+5511) 4239-3507. E-mail: borzani@maua.br 
mass in the aqueous phase, and 0.511 is the stoichiometric ethanol yield factor.

$$
\eta=\frac{M_{E}}{0.511 \cdot M_{S}} \cdot 100
$$

The values of $M_{S}$ and $M_{E}$ may be calculated by Equations 2 and 3, where $S, E, V_{a i}$ and $V_{a f}$ are the glucose initial concentration, the ethanol final concentration, the initial volume of the aqueous phase $(300 \mathrm{~mL}$ in all the experiments) and the final value of the aqueous phase volume, respectively.

$$
\begin{aligned}
& M_{S}=S \cdot V_{a i} \\
& M_{E}=E \cdot V_{a f}
\end{aligned}
$$

Otherwise, calling $V$ the volume of the inoculated medium (practically constant during each test), Equations 4 and 5, where $X_{i}$ and $X_{f}$ are, respectively, the initial and the final concentrations of biomass (dry matter), and $\sigma$ and $\rho$ are, respectively, the fraction of the dry matter in the biomass and the microorganism density, may be written (1).

$$
\begin{aligned}
& V_{a i}=V \cdot\left(1-\frac{X_{i}}{\sigma \cdot \rho}\right) \\
& V_{a f}=V \cdot\left(1-\frac{X_{f}}{\sigma \cdot \rho}\right)
\end{aligned}
$$

As $V_{a i}$ is known (0.300L in all the tests), Equations 4 and 5 permit to calculate $V$ and $V_{a f}$ in each experiment. The values of $\sigma$ and $\rho$ were, respectively, 0.300 (dry matter content of the biomass, $30.0 \%$ ) and $1.10 \cdot 10^{3} \mathrm{~g} / \mathrm{L}(2)$. It is then possible to calculated $M_{S}$ and $M_{E}$ and, consequently, $\eta$. The absolute differences between $V$ calculated by Equation 4 and the corresponding values of $V$ calculated by the ratio mass/density are smaller than $0.5 \mathrm{~mL}$.

Calling $\eta_{t}$ the fermentation efficiency calculated considering also the intracellular ethanol at fermentation completion, Equation 6, where $M_{E t}$ is the mass of intracellular ethanol plus the mass of ethanol in the aqueous phase, must be used.

$$
\eta_{t}=\frac{M_{E t}}{0.511 \cdot M_{S}} \cdot 100
$$

The value of $M_{E t}$ is calculated by Equation 7, since the intracellular ethanol concentration is equal to the concentration of ethanol in the aqueous phase $(3,7)$.

$$
M_{E t}=E \cdot V
$$

Tables 1 and 2 show, respectively, the results of the experiments and the values calculated by Equations 1 to 7 .

Table 1. Influence of the initial concentrations of glucose $(S)$ and biomass $\left(X_{i}\right)$ on the final concentrations of biomass $\left(X_{f}\right)$, ethanol $(E)$ and glycerol $(G)$.

\begin{tabular}{ccrcccc}
\hline $\begin{array}{c}\text { Test } \\
\text { number }\end{array}$ & $\begin{array}{c}S \\
(g / L)\end{array}$ & $\begin{array}{c}X_{i} \\
(g / L)\end{array}$ & $\begin{array}{c}X_{f} \\
(g / L\end{array}$ & $\begin{array}{c}E \\
(g / L)\end{array}$ & $\begin{array}{c}G \\
(g / L)\end{array}$ & $\begin{array}{c}X_{f}-X_{i} \\
(g / L)\end{array}$ \\
\hline 1 & & 7.4 & 14.0 & 38.5 & 4.4 & 6.6 \\
2 & 100.0 & 21.7 & 31.8 & 36.8 & 4.6 & 10.1 \\
3 & & 45.1 & 54.4 & 34.0 & 3.8 & 9.3 \\
\hline 4 & & 6.8 & 15.3 & 57.9 & 4.7 & 8.5 \\
5 & 150.0 & 21.3 & 28.5 & 55.3 & 4.4 & 7.2 \\
6 & & 45.5 & 54.9 & 50.8 & 4.2 & 9.4 \\
\hline 7 & & 7.5 & 15.0 & 82.1 & 5.6 & 7.5 \\
8 & 200.0 & 19.1 & 26.1 & 79.1 & 5.2 & 7.0 \\
9 & & 46.5 & 57.8 & 72.1 & 5.5 & 11.3 \\
\hline
\end{tabular}

Table 2. Values calculated from the results of Table 1 by Equations 1 to 7.

\begin{tabular}{cccccccc}
\hline $\begin{array}{c}\text { Test } \\
\text { number }\end{array}$ & $\begin{array}{c}M_{S} \\
(g)\end{array}$ & $\begin{array}{c}V \\
(L)\end{array}$ & $\begin{array}{c}V_{a f} \\
(L)\end{array}$ & $\begin{array}{c}M_{E} \\
(g)\end{array}$ & $\begin{array}{c}M_{E t} \\
(g)\end{array}$ & $\begin{array}{c}\eta \\
(\%)\end{array}$ & $\begin{array}{c}\eta_{t} \\
(\%)\end{array}$ \\
\hline 1 & & 0.307 & 0.294 & 11.3 & 11.8 & 73.7 & 77.0 \\
2 & 30.0 & 0.321 & 0.290 & 10.7 & 11.8 & 70.0 & 77.0 \\
3 & & 0.347 & 0.290 & 9.9 & 11.8 & 64.6 & 77.0 \\
\hline 4 & & 0.306 & 0.292 & 16.9 & 17.7 & 73.5 & 77.0 \\
5 & 45.0 & 0.321 & 0.293 & 16.2 & 17.8 & 70.5 & 77.4 \\
6 & & 0.348 & 0.290 & 14.7 & 17.7 & 63.9 & 77.0 \\
\hline 7 & & 0.307 & 0.293 & 24.1 & 25.2 & 78.6 & 82.2 \\
8 & 60.0 & 0.318 & 0.293 & 23.2 & 25.1 & 75.7 & 81.9 \\
9 & & 0.349 & 0.288 & 20.8 & 25.2 & 67.8 & 82.2 \\
\hline
\end{tabular}

$M_{S}=$ glucose initial mass. $V=$ fermenting medium volume. $V_{a f}=$ aqueous phase final volume. $M_{E}=$ final mass of ethanol disregarding the intracellular ethanol. $M_{E t}=$ final mass of ethanol considering also the intracellular ethanol. $\eta=$ fermentation efficiency calculated from $M_{E}$ and $M_{S} . \eta_{t}=$ fermentation efficiency calculated from $M_{E t}$ and $M_{S}$.

Table 1 clearly shows that the influence of $X_{i}$ on $\eta$ is not a consequence of the produced quantities of biomass $\left(X_{f}-X_{i}\right)$ and/or glycerol. Otherwise, Table 2 shows that, for each medium composition, the total mass of ethanol (intracellular plus extra cellular ethanol) at fermentation completion was not affected by the biomass concentration. The influence of $X_{i}$ on $\eta$ seems then to be due to the fact that $X_{f}$ increases when $X_{i}$ increases; consequently, the mass of intracellular ethanol increases and 
the mass of ethanol in the medium aqueous phase diminishes leading to a lower value of $\eta$.

It seems advisable to correlate $\eta$ and $X_{i}$. Combining Equations 1 to 7 , Equation 8 was obtained.

$$
\frac{\eta}{\eta_{t}}=1-\frac{X_{f}}{\sigma \cdot \rho}
$$

Otherwise, Equation 9 (8), where $\alpha$ and $\beta$ are empirical constants that depend on the experimental conditions, correlates $X_{f}$ and $X_{i}$.

$$
X_{f}=\alpha+\beta \cdot X_{i}
$$

Equations 8 and 9 lead to Equation 10, that is, $\eta$ linearly decreases when $X_{i}$ increases.

$$
\eta=\eta_{t} \cdot\left(1-\frac{\alpha}{\sigma \cdot \rho}\right)-\frac{\eta_{t} \cdot \beta}{\sigma \cdot \rho} \cdot X_{i}
$$

From the values of $X_{i}$ and $X_{f}$ of Table 1, Equation 11 was obtained.

$$
\begin{gathered}
X_{t}=6.89+1.067 \cdot X_{i} \\
(r=0.998)
\end{gathered}
$$

In this case, the values of $\alpha$ and $\beta$ (Eq. 9) are $6.89 \mathrm{~g} / \mathrm{L}$ and 1.067 , respectively. Equation 10, remembering that $\sigma \rho=330 \mathrm{~g} / \mathrm{L}$, leads then to Equations 12 (when $S=100.0 \mathrm{~g} / L ; \eta_{t}=77.0 \%$ ), 13 (when $S=150.0 \mathrm{~g} / \mathrm{L} ; \eta_{t}=77.1 \%$ ) and 14 (when $S=200.0$ $\left.g / L ; \eta_{t}=82.1 \%\right)$.

$$
\begin{aligned}
& \eta=75.39-0.2439 \cdot X_{i} \\
& \eta=75.49-0.2493 \cdot X_{i} \\
& \eta=80.38-0.2654 \cdot X_{i}
\end{aligned}
$$

The absolute differences between $\eta$ calculated by Equations 12 to 14 and the corresponding values of $\eta$ of Table 2 varied from $0.1 \%$ to $0.4 \%$ (average, $0.22 \%$; standard deviation, $0.10 \%$ )

If the fermentation process involves the recycle of cells, as the process developed by Les Usines de Melle for the industrial production of ethanol, the inoculum of the fermentation medium is the biomass that was separated (usually by centrifugation) from a previous completed fermentation. In other words, the yeast cells of the inoculum already contain ethanol. In this case, in spite of the fact that some new cells are frequently produced, the influence of the initial biomass concentration on the fermentation efficiency is very probably insignificant.

All things considered, it is indispensable to inform which method (Eq. 1 or Eq. 6) was used to calculated the fermentation efficiency, mainly when the fermentation process does not involve the recycle of cells.

\section{ACKNOWLEDGMENTS}

The author gratefuly acknowledges the technical assistance of Douglas Dalla Justina.

\section{RESUMO}

\section{Fermentação alcoólica descontínua: a correlação entre o rendimento da fermentação e a concentração inicial de biomassa depende do que se considere etanol produzido}

Embora muitos estudos tenham avaliado muitos dos fatores que afetam a eficiência da fermentação etanólica, a influência da concentração da biomassa na eficiência do processo tem recebido pouca atenção. Esse trabalho mostra que a influencia da concentração inicial de biomassa depende do que se considera "etanol produzido". Se, terminada a fermentação, considera-se como etanol produzido apenas aquele existente na fase aquosa do meio, o rendimento da fermentação decresce linearmente quando a concentração inicial de biomassa aumenta. Entretanto, se o etanol intracelular também é considerado, a concentração da biomassa não afeta o rendimento da fermentação.

Palavras-chave: rendimento da fermentação alcoólica, etanol intracelular, concentração de biomassa

\section{REFERENCES}

1. Borzani, W. Calculation of fermentation parameters from the results of a batch test taking account of the volume of biomass in the fermenting medium. Biotechnol Lett, 25, 1953-1956, 2003. See Erratum, Biotechnol Lett., 26, 357-362, 2004.

2. Borzani, W.; Vairo, M.L.R. Determination of the volume fraction of yeast cells in a sediment or in a suspension. Biotechnol. Lett., 5, 247-252, 1983

3. Dombeck, K.M.; Ingram, L.O. Determination of the intracellular ethanol concentration of ethanol in Saccharomyces cerevisiae during fermentation. Appl. Environ. Microbiol., 51, 197-200, 1986.

4. Falcone, M.; Vairo, M.L.R.; Borzani, W. Influência da concentração inicial de leveduras no tempo e no rendimento da fermentação alcoólica de mosto de melaço. I. Inoculação do mosto com fermento prensado. An. Farm. Quím. S. Paulo, 12, 77-83, 1961.

5. Gattas, E.A.L.; Tininis, C.R.C.S.; Laluce, C. Cheap assay of malate, glycerol and ethanol in fermented musts and food samples. Clin. Chem. Lab. Med., 41, 383-386, 2003.

6. Joslyn, M.A. Methods in Food Analysis. Academic Press, New York, 1970.

7. Pamment, N.B.; Dasari, G. Intracellular ethanol concentration and its estimation. In: van Udden (ed) Ethanol Inhibition in Yeasts and Bacteria. CRC Press, Boca Raton, Florida, 1988, p. 147-192.

8. Queiroz, M.F.V.; Vairo, M.L.R.; Borzani, W. Influence of initial yeasts and sugar concentration on the quantity of yeast produced in batch ethanol fermentation of sugar-cane blackstrap molasses. $J$. Ferment. Technol., 61, 215-218, 1983. 